Aleksandra Drozd

ORCID: 0000-0001-5271-9082

Uniwersytet Wrocławski

283254@uwr.edu.pl

\title{
Ocena ryzyka i efektywności inwestycji na rynku metali szlachetnych
}

Artykuł nadesłany: 20.04.2020; artykuł zaakceptowany: 30.04.2020

Kody klasyfikacji JEL: G11, G23

Keywords: investment funds, insurance capital funds, precious metals market, risk, efficiency

\begin{abstract}
Risk assessment and investment effectiveness on the precious metals market

Objective - analysis of risk and efficiency of investments in investment funds and insurance capital funds on the precious metals market. The basic research problem was the answer to the question whether investing in investment funds and in insurance capital funds on the precious metals market is effective and what is the risk involved. The analysed period is not a period of market downturn. The period from 30.09.2014 to 06.10.2019 is analysed. The collected data are weekly.
\end{abstract}

\section{Wprowadzenie}

Inwestycje na rynku papierów wartościowych są bardzo istotnym elementem polskiej gospodarki. W związku z rosnącym zainteresowaniem tematem funduszy inwestycyjnych, poszukiwaniem nowych sposobów inwestowania i pozyskiwania pieniędzy konieczne stało się podjęcie działań zmierzających do oceny ryzyka ponoszonego przez inwestorów i osiągnięcia potencjalnych korzyści wynikających z inwestycji. Klienci instytucji wspólnego inwestowania szukają takich funduszy, które umożliwią im uzyskanie wyższych stóp zwrotu niż bardziej bezpieczne inwestycje, takie jak lokaty bankowe.

Natomiast ubezpieczeniowe fundusze kapitałowe (dalej: UFK) są wydzielonym funduszem aktywów stanowiących rezerwę ze składek ubezpieczeniowych. Środki są inwestowane w sposób ustalony w umowie z towarzystwem ubezpie- 
czeniowym. Produkt łączy w sobie cechy ochronne i inwestycyjne. UFK nie są instytucjami prawa w sensie podmiotowym, zapewniają pewne preferencje podatkowe. Istotną wadą są koszty związane z udziałem osoby trzeciej - towarzystwa ubezpieczeń (Cwynar et al., 2016, 31-33).

Z kolei rynek metali szlachetnych stanowi alternatywę dla klasycznych instrumentów inwestowania. Przez lata metale zyskiwały na wartości i łączyły się z pojęciem władzy. Na początku były wykorzystywane do produkcji biżuterii i monet, a z czasem stały się sposobem alokacji kapitału, stanowiącym zabezpieczenie zwłaszcza w okresie kryzysu. Charakteryzują się niezniszczalnością, ponadnarodowością, niezależnością od innych zasobów, a zwłaszcza od rynku finansowego, odpornością na zmiany giełdowe. Jedną z ważnych funkcji metali szlachetnych jest to, że w niektórych krajach są przedmiotem rezerw banku centralnego. Ponadto analitycy rynkowi uważają inwestycje w złoto za fundament wszelkich inwestycji, ponieważ jako jedyne praktycznie nie wiążą się z ryzykiem i są ponadczasowe (Wojtasińska, 2017, 127-129). Ze względu na swoją specyfikę powinny być traktowane jako inwestycja długookresowa, a co za tym idzie są przeznaczone dla osób dysponujących większymi zasobami gotówkowymi (Gierałtowska, 2013, 98-99).

Wynik działalności funduszu inwestycyjnego nie może opierać się tylko na średniej stopie zwrotu. Należy pamiętać, że taka metoda oceny daje niepełny obraz funduszu: wysokie stopy zwrotu zachęcają nowych klientów do inwestowania, jednak historyczne dane nie gwarantują osiągnięcia podobnych wartości w przyszłości. Dlatego konieczna jest analiza ryzyka. Do celów niniejszej pracy najbardziej przydatna jest definicja, która mówi, że ryzyko to potencjalna zmienność zdarzeń. $Z$ tego wynika, że jest obecne w każdej dziedzinie życia. Jest pojęciem obiektywnym, a więc mierzalnym (Janasz, 2016, 88).

Celem pracy jest zbadanie ryzyka i efektywności inwestowania $\mathrm{w}$ fundusze inwestycyjne na rynku metali szlachetnych. Efektywność została zbadana pod kątem analizy osiąganych stóp zwrotu. Ze względu na poszukiwanie coraz nowszych metod inwestowania tematyka jest istotna oraz aktualna. Badaniem zostały objęte wszystkie obecnie dostępne fundusze inwestycyjne oraz ubezpieczeniowe fundusze kapitałowe. Należy podkreślić, że jak dotąd nie ma żadnych opracowań, które stanowiłyby porównanie funduszy z rynku metali szlachetnych. Ważnym elementem, będącym podstawą badań, były takie pozycje literatury, jak Treynor, Treynor on institutional investing oraz W. Sharpe, The Sharpe Ratio. Należy jeszcze uwzględnić liczne artykuły źródłowe jako punkt wyjścia pracy. W artykule zostały przedstawione badania własne dotyczące pomiaru efektywności oraz ryzyka, które zostały przeprowadzone na podstawie danych publikowanych przez zarządzających funduszami odnośnie do okresu od 30 września 2014 do 6 października 2019 roku. Warto podkreślić, że analizowany czas nie jest okresem bessy. 


\section{Efektywność funduszy inwestycyjnych}

Fundusz inwestycyjny jest swego rodzaju formą uczestnictwa inwestorów w działaniach na rynku finansowym. Łączy środki finansowe indywidualnych osób w celu zbiorowego inwestowania (Zawadzka, 2009, 28-30). Uczestnikami funduszu mogą być osoby fizyczne oraz przedsiębiorstwa. Jedni dysponują niewielkimi oszczędnościami, a drudzy dużymi nadwyżkami finansowymi. Idea wspólnego inwestowania pozwala tym dwóm różniącym się od siebie grupom na czerpanie korzyści w postaci zysku, który mógłby być dla nich niedostępny w przypadku indywidualnego inwestowania (Gabryelczyk, 2006, 24-28). W dalszej części pracy analizie zostaną poddane wszystkie aktualnie dostępne fundusze inwestycyjne oraz ubezpieczeniowej fundusze kapitałowe z rynku metali szlachetnych. Zebrane dane mają charakter tygodniowy. Analizą został objęty okres pięciu lat — jest to maksymalny okres ze względu na dostępność danych. Badany czas nie jest okresem bessy na rynkach.

Analiza efektywności to proces pomagający w ocenie i wyborze odpowiedniej inwestycji, której wyniki mierzone są przez zarządzających przede wszystkim stopą zwrotu. Podstawowe informacje, jakich zatem potrzebujemy, to statystyki dotyczące uzyskiwanych stóp zwrotu. Stopa zwrotu to procentowa zmiana stanowiąca podstawową miarę określającą, jaki dochód przypada na każdą zainwestowaną jednostkę kapitału wyrażona wzorem (Mayo, 2014, 133-136):

$$
R_{t}=\frac{\Delta X_{t}}{X_{t-1}}=\frac{X_{t}-X_{t-1}}{X_{t-1}}
$$

Gdy obserwuje się niestacjonarność względem wariancji, konieczne jest zastosowanie transformaty logarytmicznej, czyli logarytmicznej stopy zwrotu.

$$
R_{t}=\ln \left(\frac{X_{t}}{X_{t-1}}\right)
$$

gdzie:

$R_{t}$ - logarytmiczna stopa zwrotu

$X_{t}$ - wartość obecna,

$X_{t-1}$ - wartość z okresu poprzedzającego.

Logarytmiczna stopa zwrotu uznawana jest za miarę zyskowności inwestycji, ponieważ unaocznia inwestorowi, jak zachowuje się jego inwestycja i tym samym pozwala mu kontrolować jej przebieg. Oprócz oczekiwanej stopy zwrotu inwestycji w analizowanym okresie wyznaczane są również:

$R_{f}$ - oczekiwana stopa wolna od ryzyka, 
$R_{M}$ - oczekiwana stopa zwrotu z punktu odniesienia, czyli rynku (opisanego przez benchmark),

$R_{W}$ - wzorcowa stopa zwrotu.

Przez stopę wolną od ryzyka rozumie się stopę zwrotu z instrumentów finansowych z zerowym ryzykiem. Informuje ona nas o tym, jaki możemy osiągnąc minimalny zysk przez inwestowanie $\mathrm{w}$ instrumenty finansowe bez ryzyka. Zwrot pierwotnego kapitału, jak i płatności odsetek, są pewne. Może być określona przez stopę zwrotu inwestycji w papiery wartościowe emitowane przez rząd państwa, najczęściej w obligacje lub bony skarbowe. W analizowanym przypadku jako stopę wolną od ryzyka wybieramy TBSP. Index dla obligacji skarbowych jest publikowany od 16 lutego 2011 roku. Wzorcowa stopa zwrotu to minimalna akceptowalna stopa założona przez inwestora.

Należy zauważyć, że sama ocena osiąganej stopy zwrotu nie pozwala na pełną ocenę inwestycji, konieczna jest również ocena jej ryzyka. Ryzyko inwestycji można rozumieć jako możliwość zrealizowania stopy dochodu z inwestycji różniącej się od stopy dochodu, jakiej spodziewa się inwestor. Rozróżnia się trzy podstawowe rodzaje ryzyka związanego z inwestycją:

- całkowite

- systematyczne

- negatywne.

Ryzyko negatywne mam miejsce, gdy zrealizowana stopa dochodu jest niższa niż oczekiwana, a pozytywne - gdy zrealizowana stopa dochodu jest wyższa niż oczekiwana. Jako sposób oceny ryzyka zastosujemy oceny ilościowe, które w tym kontekście inwestycyjnym dzieli się na ryzyko systematyczne, całkowite i negatywne. Ryzyko systematyczne tyczy się rynku giełdowego, a związane jest z całym systemem. Powodowane jest czynnikami ogólnogospodarczymi, takimi jak polityka, i czynnikami losowymi, jak na przykład wojna. Nie da się zmniejszyć ryzyka systematycznego, bardzo trudno się zabezpieczyć przed nim zwłaszcza w czasie trwania bessy na rynku. Współczynnik $\beta$ określa zmienność wybranego waloru wobec fluktuacji na całym rynku. Daje możliwość wyjaśnienia osiągniętych stóp zwrotu z papierów wartościowych. Opiera się na założeniu, że stopy zwrotu są kształtowane przez zdeterminowane czynniki, które odzwierciedlają zmiany na rynku kapitałowym. W obliczeniach posługujemy się wzorem (Alexander, 2008, 2-10):

$$
R_{t}=\alpha_{0}+\beta R_{M t}+\varepsilon_{t}
$$

Osiągnięta wartość ryzyka systematyczne informuje inwestorów, jak zmieni się stopa zwrotu z waloru, jeżeli stopa zwrotu z rynku wzrośnie o 1\%. Współczynnik $\beta$ w zależności od przyjętego przedziału oznacza:

$\beta<0$ - wystąpienie tego typu sytuacji jest bardzo mało prawdopodobne, ale możliwe. Gdy indeks rośnie, kurs maleje i odwrotnie; 
$\beta=0-$ oznacza akcję wolną od ryzyka, na przykład bony skarbowe;

$0<\beta \leq 1$ - fundusz charakteryzuje się małym ryzykiem, inwestowanie w niego w okresie bessy jest pożądane. Stopa zwrotu waloru reaguje zdecydowanie wolniej niż rynek na zmiany;

$\beta>1$ - fundusze charakteryzują się dużym ryzykiem, stopa zwrotu waloru reaguje nadproporcjonalnie na zmiany stopy zwrotu z portfela rynkowego.

Ryzyko całkowite stanowi sumę ryzyka systematycznego i specyficznego konkretnego portfela. Miarą tego typu ryzyka jest odchylenie standardowe od stóp zwrotu. Ryzyko negatywne jest związane ze stopami mniejszymi od minimalnej akceptowalnej przez inwestorów stopy zwrotu. Do pomiaru wykorzystuje się semiodchylenie. Obliczając, najpierw należy wybrać te stopy zwrotu, które w danych okresach są ujemne, a następnie obliczyć dla nich odchylenie (Jajuga, 2012, 179-182).

\section{Miary efektywności}

Dopełnieniem oceny inwestycji jest wykorzystanie względnych miar efektywności, a cechą wspólną tych mierników jest oparcie ich na koncepcji tak zwanej premii za ryzyko. Miary te dzieli się na klasyczne i alternatywne. Najbardziej popularne względne miary klasyczne to miary:

- Treynora,

- Sharpe'a,

- Jensena.

Każdy z tych wskaźników wywodzi się od modelu wyceny CAPM. Jest to model wyceny aktywów kapitałowych — najpopularniejszy model służący do wyboru najbardziej efektywnego portfela zawierającego inwestycje kapitałowe. Opiera się na założeniu, że wymagana stopa zwrotu z inwestycji jest zależna od stopy zwrotu możliwej do osiągnięcia z instrumentów, które są wolne od ryzyka i od premii za podjęte ryzyko inwestycyjne (Jamróz, 2013, 194). Wskaźnik Traynora jest to iloraz nadwyżkowej stopy zwrotu funduszu i ryzyka systematycznego. Wyraża się wzorem (Treynor, 2007,6):

$$
T_{p}=\frac{R_{p}-R_{f}}{\beta_{p}}
$$

$R_{p}-R_{f}$ - nadwyżkowa stopa zwrotu funduszu, $B_{p}$ - ryzyko systematyczne.

Wskaźnik Treynora uwzględnia tylko ryzyko systematyczne. Im wyższa wartość wskaźnika, tym lepsze wyniki osiągane dla zarządzającego portfelem. Dodatnia wartość oznacza, że badany portfel charakteryzuje się wyższą stopą zwrotu od stopy wolnej od ryzyka. 
Następnym wskaźnikiem jest klasyczna miara Sharpe'a, nazywana także wynagrodzeniem za zmienność. Informuje o tym, że inwestor chce ponieść większe ryzyko, ale tylko gdy otrzyma proporcjonalnie wyższe zyski. Jest to iloraz nadwyżkowej stopy zwrotu funduszu i ryzyka całkowitego. Wyraża się wzorem (Sharpe, 1994, 2-5):

$$
S_{p}=\frac{R_{p}-R_{f}}{\sigma_{p}}
$$

$R_{p}-R_{f}$ - nadwyżkowa stopa zwrotu funduszu $\sigma_{p}$ - ryzyko całkowite

Wskaźnik ten informuje, w jakim stopniu stopa zwrotu wynagrodzi inwestorowi ponoszone przez niego ryzyko. Wyższa wartość tego współczynnika oznacza wyższe stopy zwrotu przy takim samym ryzyku. Natomiast ujemne wartości oznaczają, że portfel osiąga niższą stopę zwrotu od stopy wolnej od ryzyka.

Ostatnia omawiana w artykule miara klasyczna to wskaźnik Jensena. Jest on swego rodzaju modyfikacją wskaźnika Treynora. Wartość tego wskaźnika określa, w jakim stopniu stopa zwrotu z portfela przedstawia wyższe średnie zwroty, które uwzględniają ryzyko. Wyraża się go za pomocą wzoru (Jensen, 1964, 2-6):

$$
\alpha_{p}=\left(R_{p}-R_{f}\right)-\beta\left(R_{m}-R_{f}\right)
$$

$R_{p}-R_{f}$ - nadwyżkowa stopa zwrotu funduszu

$\beta$ - ryzyko systematyczne

$R_{m}-R_{f}$ - nadwyżkowa stopa zwrotu

Dodatnia wartość tego wskaźnika świadczy o skutecznym działaniu zarządzającego — o tym, że potrafi on przewidzieć wahania rynku lub dokonywać konsekwentnie wyborów. Jest to miara absolutna, dlatego też nie należałoby używać tego wskaźnika do porównań portfeli o różnych poziomach ryzyka. Im wyższa wartość współczynnika, tym większa jego atrakcyjność. Gdy dany fundusz jest dobry z perspektywy wskaźnika Sharpe'a i Treynora, a wskaźnik Jensena wychodzi niekorzystny, to należałoby skorygować wartości.

Dotychczas przedstawiono klasyczne miary stosowane do pomiaru efektywności funduszy inwestycyjnych. Jak się okazuje, nie są one jedyną grupą. Należy jeszcze uwzględnić alternatywne miary ryzyka. Są to: Sortino, UPR i Omega. Sortino zakłada, że inwestorzy bardziej obawiają się nieuzyskania oczekiwanej stopy zwrotu z funduszu aniżeli jego zmienności. Miara ta uwzględnia zatem tylko straty mierzone 
stopą zwrotu. Poza tym jest bardzo podobny do wskaźnika Sharpa (Homa, Mościbrodzka, 2018, 5). Liczy się go według wzoru (Rollinger, Hoffman, 2015, 3-5):

$$
\operatorname{SoR}=\frac{R_{p}-R_{w}}{\sigma_{w}}
$$

$R_{p}-R_{w}$ - nadwyżkowa stopa zwrotu funduszu inwestycyjnego $\sigma_{w}$ - ryzyko negatywne

Współczynnik ten jest obliczany w celach porównawczych po to, aby sprawdzić, jak menadżer radzi sobie z kontrolowaniem ryzyka. Im wyższa wartość, tym teoretycznie mniej ryzykowny portfel. Jest to miernik istotny z punktu widzenia inwestującego, ponieważ poniekąd pokazuje klasę zarządzającego. Wartość dodatnia odzwierciedla straty, jakie możemy ponieść, pokazuje, czy jest promowane ryzyko negatywne. Wartość dodatnia świadczy o tym, że straty są rekompensowane przez odpowiedni zwrot $\mathrm{z}$ inwestycji.

Następnym miernikiem $\mathrm{z}$ tej grupy jest UPR. Jego licznik uwzględnia nadwyżkę ponad próg rentowności. Stosuje się tu wzór (Karpio, Żebrowska-Suchodolska, 2015, 4):

$$
U P R=\frac{\frac{1}{N-1} \sum\left(R_{p t}-R_{w}\right)}{\sigma_{w}}
$$

Wskaźnik UPR to stosunek odchyleń pozytywnych do odchyleń negatywnych, czyli do semiodchylenia. W przypadku tego wskaźnika mierzy się odchylenie od minimalnej wymaganej stopy. Informuje inwestorów o tym samym co Sortino, ale z uwzględnieniem progu rentowności. Pokazuje, jak zyski premiują ryzyko straty. Obrazuje, czy w okresach zysków jesteśmy w stanie pokryć ponoszone straty.

Ostatnim z tej grupy jest wskaźnik Omega. Jest to stosunek średniej stopy zwrotu, która jest powyżej progu rentowności, do średniej stopy zwrotu poniżej progu. Do obliczeń stosuje się wzór (Michalska, Dudzińska-Baryła, 2015, 2):

$$
\Omega=\frac{\sum\left(R_{p t}-R_{w}\right)}{\mid \sum\left(R_{p t}-R_{w} \mid\right.}
$$

Obrazuje rozpiętość między maksymalnymi zyskami a minimalnymi stratami. W kontekście inwestowania jest w stanie pokazać, jak dużo inwestor może zarobić w odniesieniu do strat. Służy do wskazania funduszu, który najlepiej odzwierciedla oczekiwania inwestorów. Największą wartość pokaże fundusz, który da największy zarobek przy najmniejszym ryzyku. 


\section{Wyniki badań}

Analiza pozwala często znaleźć „słabe punkty” inwestycji ze szczególnym zwróceniem uwagi na to, czy dobre wyniki, jakie osiągają zarządzający, mają szansę się powtórzyć, czy też są przypadkowym wynikiem. Analizą objęto więc okres od dnia 30 września 2014 do 6 października 2019 roku i objęto nią fundusze:

- Investor Gold Otwarty,

- Quercus Gold,

- Superfund Goldfuture,

- Investor Gold Otwarty UFK,

- Europa Quercus Gold otwarty UFK.

W analizie zostały uwzględnione wszystkie obecnie dostępne fundusze z grupy metali szlachetnych, których okres trwania funduszu wynosi co najmniej 5 lat, od 30 września 2014 roku do 6 października 2019 roku. Należy zwrócić uwagę na istotny czynnik, jakim jest tygodniowy charakter zebranych danych. Fundusze inwestycyjne oraz ubezpieczeniowe fundusze kapitałowe objęte badaniem wraz $\mathrm{z}$ ich benchmarkami przedstawiono w tabeli 1 .

Tabela 1. Fundusze i odpowiadające im benchmarki

\begin{tabular}{|c|c|c|c|}
\hline & Fundusz & & Benchmark \\
\hline F1 & Investor Gold Otwarty & B1 & $90 \%$ GOLD + 10\% WIBID 6M \\
\hline F2 & Quercus Gold & B2 & $100 \%$ COMEX \\
\hline F3 & Superfund Goldfuture & B3 & $100 \%$ GOLD \\
\hline F4 & Investor Gold Otwarty UFK & B4 & $90 \%$ GOLD + 10\% WIBID 6M \\
\hline F5 & Europa Quercus Gold otwarty UFK & B5 & $100 \%$ COMEX \\
\hline
\end{tabular}

Źródło: opracowanie własne na podstawie danych zebranych z kart funduszy z portalu analizy.pl (dostęp: 6.11.2019).

Benchmark to wskaźnik opisujący strategię inwestycyjną, jest zatem punktem odniesienia, z którym porównujemy naszą inwestycję. Jak pokazuje tabela, w wypadku analizowanych danych benchmarkiem jest COMEX, GOLD oraz WIBID 6M.

Ze względu na niestacjonarność wszystkich szeregów czasowych dla badanych funduszy analizę efektywności ryzyka oparto na logarytmicznej stopie zwrotu, która stanowiła podstawę wyznaczenia oczekiwanej stopy zwrotu z inwestycji wraz z jej ryzykiem całkowitym, systematycznym i negatywnym. Wyniki przedstawiono $\mathrm{w}$ tabeli 2.

W badanym okresie tylko jeden fundusz nie zarobił, a najlepszymi okazały się fundusz Investor Gold Otwarty i Investor Gold Otwarty UFK. Co ciekawe, fundusze te mają wszystkie charakterystyki rozkładu identyczne, a dokładniejsza analiza, której wyniki zostaną przedstawione w dalszej części artykułu, wykazała, że są to takie same fundusze, jednak zarządzający podają je jako dwa odmienne: jeden jako 
fundusz inwestycyjny, a drugi jako ubezpieczeniowy fundusz kapitałowy. Przeczy to stawianej hipotezie, zgodnie z którą fundusze UFK powinny być bezpieczniejsze ze względu na specyfikę ich działalności. Poza tym wszystkie z analizowanych funduszy tracą względem rynku, co oznacza, że zarządzający nie działają efektywnie w zakresie prowadzonej strategii inwestycyjnej. Pośród omawianych funduszy tylko Superfund Goldfuture deklaruje korzystanie ze strategii zabezpieczającej typu hedge, jednak jest to jedyny fundusz, który w badanym okresie wykazał stratę mimo zysków, jakie dawał wówczas rynek. Może to być pierwszy sygnał dla inwestorów, że zarządzający nie stosują poprawnie strategii zabezpieczających.

Tabela 2. Efektywność funduszy i ich rynku

\begin{tabular}{|c|c|c|c|}
\hline \multicolumn{2}{|c|}{ Fundusz } & \multicolumn{2}{c|}{ Oczekiwany zwrot [\%] } \\
\cline { 3 - 4 } \multicolumn{2}{|c|}{} & FI & RYNEK \\
\hline F1 & Investor Gold Otwarty & 0,04 & 0,15 \\
\hline F2 & Quercus Gold & 0,02 & 0,06 \\
\hline F3 & Superfund Goldfuture & $-0,02$ & 0,15 \\
\hline F4 & Investor Gold Otwarty UFK & 0,04 & 0,15 \\
\hline F5 & Europa Quercus Gold otwarty UFK & 0,02 & 0,06 \\
\hline
\end{tabular}

Źródło: opracowanie własne na podstawie własnych obliczeń.

Należy zauważyć, iż ocena inwestycji wyłącznie pod kątem osiąganej stopy zwrotu jest analizą niepełną, nie uwzględnia bowiem oceny ich ryzyka, a jest to obok dochodu/zysku podstawowa charakterystyka inwestycji. W bardzo ogólny i prosty sposób ryzyko inwestycji można określić jako możliwość zrealizowania stopy dochodu inwestycji różniącej się od stopy dochodu, której spodziewa się inwestor.

Tabela 3. Ryzyko funduszy

\begin{tabular}{|c|c|c|c|c|c|}
\hline \multirow{2}{*}{ Fundusz } & \multicolumn{2}{|c|}{ Ryzyko całkowite [\%] } & \multicolumn{2}{|c|}{ Ryzyko negatywne [\%] } & $\begin{array}{c}\text { Ryzyko syste- } \\
\text { matyczne }\end{array}$ \\
\cline { 2 - 6 } & FI & RYNEK & FI & RYNEK & FI \\
\hline F1 & 1,76 & 1,77 & 1,02 & 1,00 & $1,58 \mathrm{E}-38$ \\
\hline F2 & 1,78 & 1,37 & 1,03 & 0,73 & $1,07 \mathrm{E}-08$ \\
\hline F3 & 3,30 & 1,77 & 2,14 & 1,00 & $7,60 \mathrm{E}-08$ \\
\hline F4 & 1,76 & 1,77 & 1,02 & 1,00 & $1,58 \mathrm{E}-38$ \\
\hline F5 & 1,78 & 1,37 & 1,03 & 0,73 & $1,07 \mathrm{E}-08$ \\
\hline
\end{tabular}

Źródło: opracowanie własne na podstawie własnych obliczeń.

Dodatnie oraz istotne ryzyko systematyczne oznacza, że zarządzający funduszem reagują na zmiany zachodzące na rynku. W przypadku ryzyka systematycznego wszystkie analizowane fundusze wykazują istotne i dodatnie wartości. Może 
to oznaczać, że zarządzający patrzą na rynek, reagują na zmiany na nim zachodzące. W najgorszym położeniu znajduje się fundusz 3, ponieważ inwestując w niego, ponosimy duże ryzyko i osiągamy mały zysk. Powtórzenie wartości przy różnych funduszach może oznaczać, że fundusze podawane przez zarządzających jako różne tak naprawdę są dokładnie tym samym funduszem. Świadczy to o możliwej próbie „naciągania” inwestorów. Dla ryzyka całkowitego fundusze oraz ich rynki osiągają zbliżone wartości, mniejsze od wartości funduszy, co może świadczyć o tym, że rynek traci mniej niż fundusz. Wyjątkiem jest fundusz 3, którego ryzyko jest dwa razy większe niż jego rynku. Świadczy to, że inwestując, ponosimy duże ryzyko, a efektywność inwestycji jest mała. W przypadku ryzyka negatywnego wszystkie fundusze osiągają wyższe wartości niż rynek. Dwa razy większy wskaźnik ryzyka negatywnego ma fundusz 3, co może wskazywać na ponoszone duże ryzyko inwestycyjne i osiąganą małą efektywność. Nie zostały sporządzone mapy ryzyka od efektywności funduszu, ponieważ fundusze 1 i 4 oraz 2 i 5 tworzą ten sam fundusz.

Zastosowanie omówionych miar bezwzględnych stanowi podstawę dalszych analiz uwzględniających złożony charakter inwestycji i stanowiących sposób pomiaru stopy zwrotu w relacji do ponoszonego ryzyka, co oznacza konieczność zastosowania miar względnych. Cechą wspólną wszystkich tych miar jest oparcie ich na koncepcji premiowania za ryzyko. Wyznaczone wartości klasycznych miar zostały przedstawione w tabeli 4 .

Tabela 4. Klasyczne miary ryzyka

\begin{tabular}{|c|c|c|c|c|c|}
\hline Fundusz & $\mathrm{Sp}[\%]$ & $\sigma[\%]$ & $\mathrm{Tp}$ & Sor [\%] & Omega [\%] \\
\hline F1 & $-1,29$ & $-0,02$ & $-1,43 \mathrm{E}+34$ & $-2,21$ & 106,58 \\
\hline F2 & $-2,54$ & $-0,05$ & $-4,21 \mathrm{E}+04$ & $-4,39$ & 102,88 \\
\hline F3 & $-2,55$ & $-0,08$ & $-1,11 \mathrm{E}+04$ & $-3,94$ & 98,40 \\
\hline F4 & $-1,29$ & $-0,02$ & $-1,43 \mathrm{E}+34$ & $-2,21$ & 106,58 \\
\hline F5 & $-2,54$ & $-0,05$ & $-4,21 \mathrm{E}+04$ & $-4,39$ & 102,88 \\
\hline
\end{tabular}

Źródło: opracowanie własne na podstawie własnych obliczeń.

Według współczynnika Sharpe’a fundusze osiągają mniejszą stopę zwrotu od stopy wolnej od ryzyka. Ze wszystkich omawianych funduszy pierwszy i czwarty w największym stopniu wynagrodzi poniesione ryzyko. Następną klasyczną miarą jest współczynnik Jensena. Omawiane fundusze nie mają umiejętności skutecznego zarządzania portfelem, nie dokonują trafnych prognoz oraz nie reagują właściwie na wahania na rynku. Zarządzający funduszem 3 deklarują korzystanie ze strategii zabezpieczających, a mimo to jego wyniki są ujemne. Może to świadczyć o okłamywaniu inwestorów albo naginaniu faktów. Ostatnim klasycznym miernikiem jest współczynnik Treynora. Wszyscy inwestorzy, niezależnie od swoich preferencji w stosunku do ryzyka, powinni dążyć do maksymalizacji osiąganych wartości (Jamróz, 2013, 195-197). Analizowane fundusze wykazują ujemne wartości, stopa zwrotu z inwestycji jest mniejsza od stopy wolnej od ryzyka. Ujemne 
wartości współczynnika Traynora informują inwestorów, że nie powinni inwestować $\mathrm{w}$ żaden $\mathrm{z}$ omawianych funduszy.

Pierwszą miarą alternatywną jest wskaźnik sortino. Wartości ujemne naszych funduszy pokazują, że zarządzający nie radzą sobie z kontrolowaniem ryzyka, a straty nie są rekompensowane przez osiągane zyski. Drugim miernikiem jest omega — wskazuje fundusze 1 i 4 jako te, które najlepiej spełnią oczekiwania inwestorów: przyniosą maksymalny zysk przy minimalnej stracie.

Ponieważ omówione miary klasyczne są podstawą prawidłowego wnioskowania tylko w przypadku inwestycji, których stopy zwrotu mają rozkład normalny, wykorzystując test SW oraz badając skośność i kurtozę rozkładu, zweryfikowano rozkład empiryczny dla stóp zwrotu badanych funduszy, a wyniki przedstawiono w tabeli 5 . Nie każdy omawiany fundusz ma rozkład normalny, konieczne więc było zastosowanie alternatywnych miar ryzyka. W tym celu została przeprowadzona analiza symetrii, kurtozy oraz „ciężkości ogonów” każdego z funduszy.

Tabela 5. Analiza rozkładu normalnego

\begin{tabular}{|c|c|c|c|c|c|}
\hline \multirow{2}{*}{ Fundusz } & \multirow{2}{*}{ Symetria } & \multirow{2}{*}{ Kurtoza } & \multirow{2}{*}{ "Ciężkie Ogony" } & \multicolumn{2}{|c|}{ Test Shapiro-Wilka } \\
\hline & & & & SW & $\mathrm{P}$ \\
\hline $\mathrm{F} 1$ & tak & tak & tak & 0,987697 & 0,0250195 \\
\hline F2 & - & - & - & 0,99343 & 0,309571 \\
\hline F3 & nie & tak & tak & 0,952427 & $1,58624 \mathrm{e}-007$ \\
\hline F4 & tak & tak & tak & 0,987697 & 0,0250195 \\
\hline F5 & - & - & - & 0,99343 & 0,508939 \\
\hline
\end{tabular}

Źródło: opracowanie własne na podstawie własnych obliczeń.

Z zestawienia wynika, że tylko stopy zwrotu funduszów 2 i 5 mają rozkład normalny, a co za tym idzie nie występuje symetria, kurtoza ani „ciężkie ogony”. Pozostałe stopy zwrotu omawianych funduszy nie madają rozkładu normalnego. Tylko fundusz 3 nie charakteryzuje się symetrią. Po przeprowadzeniu analizy konieczne jest zastosowanie alternatywnych miar ryzyka.

Tabela 6. Alternatywne miary ryzyka

\begin{tabular}{|c|c|c|c|c|}
\hline Fundusz & UPR [\%] & Calmar [\%] & Sterling & Burky [\%] \\
\hline F1 & 67,30 & 0,38 & $3,78 \mathrm{E}-03$ & $-0,38$ \\
\hline F2 & 69,53 & 0,91 & nieistotne & nieistotne \\
\hline F3 & 55,66 & 0,53 & $5,52 \mathrm{E}-03$ & $-0,28$ \\
\hline F4 & 67,30 & 0,38 & $3,78 \mathrm{E}-03$ & $-0,38$ \\
\hline F5 & 69,53 & 0,91 & nieistotne & nieistotne \\
\hline
\end{tabular}

Źródło: opracowanie własne na podstawie własnych obliczeń.

Ekonomia - Wroclaw Economic Review 26/1, 2020

(C) for this edition by CNS 
Wskaźnik UPR pokazuje, jak zyski premiują ponoszone straty. Fundusze 2 i 5 najlepiej premiują ponoszone straty poprzez osiągane zyski. Miernik Calmara uwzględnia maksymalną stratę na kapitale, jaką jest możliwość wygenerowania w zadanym okresie. Największą wartość, a więc największą efektywność, osiąga ją fundusze 2 i 5 . Ponieważ wskaźnik Calmara jest bardzo wrażliwy na przypadkowe stopy zwrotu, obliczono wskaźnik Sterlinga (Pruchnicka-Grabias, 2015, 136-138). W przypadku wskaźników Sterlinga i Burky'ego nie są brane pod uwagę stopy zwrotu z funduszy, które mają rozkład normalny i nie mają ogonów. Wskaźnika Sterlinga skupia się na średniej stracie z największych strat, jakie zostały wygenerowane na kapitale. Najwyższą wartość osiąga fundusz 3, a co za tym idzie prezentuje on największą optymalną efektywność inwestycji. Ostatnim miernikiem jest wskaźnik Burky’ego. Tak jak w poprzednim przypadku fundusze 2 i 5 mają nieistotne wartości, co jest spowodowane brakiem ogona i rozkładem normalnym. $Z$ analizy danych przedstawionych w tabeli 6 wynika, że wartość wskaźnika Burky'ego jest ujemna dla każdego z omawianych funduszy. Najlepszy spośród omawianych jest fundusz 3.

\section{Podsumowanie}

Celem badań było określenie ryzyka i efektywności inwestycji w fundusze inwestycyjne na rynku metali szlachetnych. $Z$ zebranego w toku badań materiału i przeprowadzonych analiz wynika, że inwestycje na rynku metali szlachetnych są obarczone wysokim ryzykiem, a także nie pozwalają na osiągnięcie tak dużych zysków, jakie inwestorzy chcieliby osiągnąć. Podczas analizy danych przedstawionych w artykule można zauważyć, że zarządzający nie reagują właściwie na zmiany zachodzące na rynku, nie potrafią prognozować. Jak się okazuje, zarządzający funduszami pod różną nazwą umieszczają te same fundusze inwestycyjne, w ten sposób dopuszczając się drobnych oszust względem inwestorów. Opierając się na wynikach otrzymanych podczas przeprowadzonej analizy, można powiedzieć, że żaden z funduszy poddanych analizie nie spełni oczekiwań inwestorów. Badania i rozważania podjęte w pracy nie wyczerpują całokształtu problematyki związanej z ryzykiem i efektywnością inwestycji na rynku metali szlachetnych, wymagają dalszych prac. W przyszłości należałoby przeprowadzić próbę na większej grupie, uwzględniając dłuższy okres.

\section{Bibliografia}

Alexander, C. (2008). Market Risk Analysis Practical Financial Econometrics. Wiley.

Cwynar, A., Cwynar, W., Kaźmierkiewicz, P., Ostrowska-Dankiewicz, A. (2016). Efektywność ubezpieczeniowych funduszy kapitałowych w Polsce. Warszawa: Wydział Nauk Ekonomicznych Uniwersytetu Warszawskiego.

Ekonomia - Wroclaw Economic Review 26/1, 2020

(C) for this edition by CNS 
Gabryelczyk, K. (2006). Fundusze inwestycyjne rodzaje, zasady funkcjonowania, efektywność. Kraków: Oficyna Ekonomiczna.

Gierałtowska, U. (2013). Inwestowanie w metale szlachetne jako alternatywna forma lokowania kapitału. Wrocław: Wydawnictwo Uniwersytetu Ekonomicznego we Wrocławiu.

Homa, M., Mościbrodzka, M. (2018). Wykorzystanie narzędzi wielowymiarowej analizy porównawczej w badaniu jednorodności funduszy inwestycyjnych akcji pod względem ryzyka i efektywności - podejście klasyczne i alternatywne. Finanse i Rachunkowość, 4.

Jajuga, K.,T. (2012). Inwestycje. Warszawa: Wydawnictwo Naukowe PWN.

Jamróz, P. (2013). Efektywność wybranych FIO rynku akcji w latach 2003-2011. Zeszyty Naukowe Uniwersytetu Szczecińskiego. Finanse, Rynki Finansowe, Ubezpieczenia, 63.

Janasz, K. (2016). Ryzyko i niepewność w gospodarce - wybrane aspekty teoretyczne. Szczecin: Wydawnictwo Naukowe Uniwersytetu Szczecińskiego.

Jensen, M. (1964). The performance of mutual funds int the period 1945-1964. The Journal of the American Finance Association, 23.

Karpio, A., Żebrowska-Suchodolska, D. (2015). Badanie stabilności wyników funduszy inwestycyjnych przy użyciu miar opartych na współczynniku Sharpe’a. Zeszyty Naukowe Uniwersytetu Szczecińskiego, 75.

Mayo, H.B. (2014). Inwestycje. Warszawa: Wydawnictwo Naukowe PWN.

Michalska, E., Dudzińska-Baryła, R. (2015). Wskaźnik Omega w ocenie wariantów decyzyjnych o rozkładach ciągłych na przykładzie akcji notowanych na GPW w Warszawie. Zeszyty Naukowe Uniwersytetu Ekonomicznego w Katowicach, 241.

Pruchnicka-Grabias, I. (2015), Zastosowanie miar maksymalnej straty na kapitale w badaniu efektywności funduszy Hedgingowych, Warszawa: Szkoła Główna Handlowa.

Rollinger, T., Hoffman, S. (2015), Sortino: A 'Sharper'Ratio. Red Rock.

Sharpe, W. (1994). The Sharpe Ratio. The Journal of Portfolio Management, 21.

Treynor, J. (2007). Treynor on institutional investing, Willey.

Wojtasińska, A. (2017). Szanse i zagrożenia inwestycji na wybranych segmentach rynku finansowego. Łódź: Uniwersytet Łódzki.

Zawadzka, P. (2009). Fundusz inwestycyjny w systemie instytucji finansowych. Warszawa: Wydawnictwo C.H. Beck.

Ekonomia - Wroclaw Economic Review 26/1, 2020

(C) for this edition by CNS 